\title{
Review
}

\section{Construction of Building Blocks for Highly Functional $\pi$-Electron Silicon Nanomaterials by First-Principles Calculations}

\author{
Masae Takahashi
}

\author{
Graduate School of Agricultural Science, Tohoku University, Sendai 981-8555, Japan
}

\begin{abstract}
This paper reviews our computational studies on several building blocks for highly functional $\pi$-electron silicon nanomaterials by the introduction of an anionic system. We insisted that the design of building blocks possessed strictly genuine $\pi$ electrons: $\pi$-conjugation on planar/linear skeletons. Though silicon is in the same group of the periodic table as carbon, the geometric structure of the unsaturated silicon compounds is nonclassical: trans-bent at silicon-silicon double and triple bonds, and chair-like at a six-membered silicon ring. We have theoretically designed a linear siliconsilicon triple bond and a $D_{6 h}$-symmetric six-membered silicon ring with extra electrons instead of conventional substituents such as alkyl, aryl, etc. We summarize here our main findings and discuss the key points to realize the classical structure etc. in the $\pi$-electron silicon system.
\end{abstract}

Keywords: first-principles calculations, density-functional-theory calculations, $\pi$-electron silicon system, anionic silicon cluster

\section{Introduction}

Several building blocks of the $\pi$-electron silicon system designed by our computational studies are reviewed in this paper. The target is the building blocks possessing a strictly genuine $\pi$-conjugation. A common feature underlying the successfully designed building blocks is elucidated and discussed.

Fullerene, polyacetylene, and graphene provide fascinating properties governed by $\pi$ electrons in the carbon system, and the researches of these materials were sparkled with Novel prizes in 1996, 2000, and very recently in 2010, respectively. Silicon is in the same group of the periodic table as carbon and thus has a potential ability to make another paradigm produced by the $\pi$ electrons. Ethylene $\left(1, \mathrm{H}_{2} \mathrm{C}=\mathrm{CH}_{2}\right)$, acetylene $(2, \mathrm{HC} \equiv \mathrm{CH})$, and benzene (3, c- $\left.(\mathrm{CH})_{6}\right)$ are authentic building blocks of the $\pi$-electron carbon system (Fig. 1). We computed recently the corresponding building blocks of the $\pi$-electron silicon system, insisting upon a genuine $\pi$ conjugation (Takahashi and Kawazoe 2005; Takahashi and Kawazoe 2006; Takahashi and Kawazoe 2008; Takahashi 2010): the linearity of acetylene (2), and the planarity in ethylene (1) and benzene (3) are essential for the genuine $\pi$ conjugation.<smiles>C=C</smiles>

1<smiles>C[SiH3]</smiles>

4<smiles>C#C</smiles>

2<smiles>c1ccccc1</smiles>

trans-bent<smiles>[SiH]=[SiH2]</smiles>

5<smiles>[SiH2]1[SiH2][SiH2][SiH2][SiH2]1</smiles>

6
Fig. 1. Archetypical $\pi$-electron systems of carbon (1-3) and silicon (4-6). 
Earlier theoretical investigations of disilene (4, the silicon analogue of ethylene, $\left.\mathrm{H}_{2} \mathrm{Si}=\mathrm{SiH}_{2}\right)$, disilyne $(\mathbf{5}$, that of acetylene, $\mathrm{HSi}=\mathrm{SiH})$, and hexasilabenzene $(\mathbf{6}$, that of benzene, c- $\left.(\mathrm{SiH})_{6}\right)$, revealed the lack of the strictly genuine $\pi$ conjugation (Fig. 1): disilene (reviewed in (Raabe and Michl 1985)) and disilyne (Lischka and Köhler 1983) take a trans-bent geometry, and hexasilabenzene adopts a chair-like structure (Nagase et al. 1987; Nagase 1991). Disilene, disilyne, and hexasilabenzene appeal no fascination as $\pi$-electron system. Nowadays, the following explanation has been vindicated for the difference in geometry between the unsaturated carbon and silicon systems (Kutzelnigg 1984): the essential difference between the atoms of the first and higher rows is that the cores of the former contain only s-atomic orbitals, whereas the cores of the latter include at least s- and p-atomic orbitals. The s and $p$ valence atomic orbitals of first row atoms are localized in roughly the same region of space, while the $p$ valence atomic orbitals of higher row atoms are much more extended in space. This has the consequence that, for the light main group elements, isovalent hybridization plays a greater role than for the heavy main group elements.

The synthesis of unsaturated silicon compounds has an attempting and challenging history. The multiple-bond rule took a dogma-status as the golden rule in silicon chemistry for a long time (Jutzi 1975). The rule states that heavier Group 14 elements such as silicon cannot form multiple bonds because of the considerable Pauli repulsion between the electrons of inner shells. The synthesis of a stable $\mathrm{Si}-\mathrm{Si}$ double-bond compound, tetramesityldisilene, in 1981 broke through the multiple-bond rule (West et al. 1981); this is the dawn of the unsaturated silicon chemistry. The X-ray crystallographic measurement of tetramesityldisilene revealed an astonishing fact (Fink et al. 1983): tetramesityldisilene adopts a trans-bent geometry at the silicon-silicon double bond in crystal. The fact that the formally $\pi$-conjugating double-bond compound does not have a two-dimensional skeleton stimulated further syntheses of various disilenes and investigations of the structures. Twenty years on from the first synthesis of the stable disilene, a stable $\mathrm{Si}-\mathrm{Si}$ triple-bond compound, 1,1,4,4-tetrakis[bis(trimethylsilyl) methyl]-1,4-diisopropyl-2-tetrasilyne, was synthesized (Sekiguchi et al. 2004). The structure of the isolated disilyne was revealed to be trans-bent. The synthesis of a planar six-membered silicon ring is extremely challenging and very few are known. A nearly-planar hexagon consisting of silicon was found in solid-state Zintl anion: $\mathrm{Si}_{6}{ }^{10-}$ in $\mathrm{Ba}_{4} \mathrm{Li}_{2} \mathrm{Si}_{6}$ (Schnering et al. 1996). The species is geometrically similar to benzene, but is Hückel arenes with $10 \pi$ electrons. The number of $\pi$ electrons is four more than in benzene. The hexagon is coordinated on both sides by barium. Planar hexasilylhexasilacyclohexene anions $\left(\mathrm{Si}_{12}\right)$ containing $\mathrm{Si}_{6}$ ring of approximate $D_{6 h}$ symmetry was obtained in unusual Zintl phase $\left(\mathrm{Ca}_{7} \mathrm{Mg}_{7.5 \pm \delta} \mathrm{Si}_{14}\right)$ with metallic conductivity (Nesper et al. 1998), but the $\mathrm{Si}_{6}$ ring is nonaromatic.

In this review, we mainly consider our findings on building blocks in the $\pi$-electron silicon system strictly similar to the $\pi$-electron carbon system, together with the background to reach them. The construction of the rest of the paper will be separated into sections of the following topics: a planar silicon-silicon double-bond compound, a linear silicon-silicon triple-bond compound, planar $\pi$ conjugating silicon chains, and flat six-membered silicon rings. Finally, a short summary and conclusion is given.

\section{Dianionic silicon dimer with $\mathrm{Si}-\mathrm{Si}$ double bond}

Disilene with a classical planar form was theoretically obtained with an electropositive substituent $\mathrm{R}$ (e.g. $\mathrm{R}=$ $\mathrm{Li}, \mathrm{BeH}, \mathrm{BH}_{2}$, and $\mathrm{SiH}_{3}$ in $\left.\mathrm{RHSi}=\mathrm{SiH}_{2}\right)($ Karni and Apeloig 1990). In this section, we introduce a hydrogen-terminated silicon dimer, $\mathrm{H}-\mathrm{Si}_{2}-\mathrm{H}$, and the dianion, $\left[\mathrm{H}-\mathrm{Si}_{2}-\mathrm{H}\right]^{2-}$, as the smallest model compound of $\mathrm{Si}_{\mathrm{n}}$ polymer (Takahashi and Kawazoe 2006). Recently we found that charged systems are helpful for understanding systematically the stability of silicon $\pi$ systems (Takahashi and Sakamoto 2002). In contrast to cations, anions can stabilize themselves by the spontaneous emission of an electron, the so-called autodetachment. Thus, it is not a priori clear whether anions exist in the gas phase as a stable entity. Today it is well established that most of elements form atomic negative ions (reviewed in (Hotop and Lineberger 1985)). Several multiply charged anions of unsaturated silicon systems have been found in crystal, and their structures have been elucidated.

A neutral molecule with the formula of $\mathrm{Si}_{2} \mathrm{H}_{2}$ has four singlet isomers (the monobridged, the dibridged, disilavinylidene, and trans-bent disilyne) and among the four the trans-bent disilyne, that is in other word a hydrogen-terminated silicon dimer $\left(\mathrm{H}-\mathrm{Si}_{2}-\mathrm{H}\right)$ with a triple bond in trans configuration, is the least stable, as reported in previous theoretical studies (reviewed in (Jutzi 
2000)). A triplet $\mathrm{H}-\mathrm{Si}_{2}-\mathrm{H}$ has also a trans-bent structure as reported in a previous theoretical study (Koseki and Gordon 1988) and the energy is higher by $c a .2 \mathrm{kcal} / \mathrm{mol}$ than the singlet. Four singlet isomers were obtained for the dianion of $\mathrm{Si}_{2} \mathrm{H}_{2}$ and two of them are hydrogenterminated silicon dimers in trans and cis configurations. In contrast to neutral $\mathrm{Si}_{2} \mathrm{H}_{2}$ isomers, the hydrogen-terminated isomers are the most stable two among the dianionic $\mathrm{Si}_{2} \mathrm{H}_{2}$ isomers. The existence of trans and cis isomers is the same as in the carbon-carbon double-bond compound, ethylene: the ethylene derivative, $\mathrm{RHC}=\mathrm{CHR}$, has the trans and cis isomers. The trans isomer of $\left[\mathrm{H}-\mathrm{Si}_{2}-\mathrm{H}\right]^{2-}$ is more stable by $3-4 \mathrm{kcal} / \mathrm{mol}$ than the cis. The $\mathrm{H}-\mathrm{Si}-\mathrm{Si}-$ $\mathrm{H}$ dihedral angle of triplet dianion is approximate $90^{\circ}$. The twisted structure is also the same as in triplet ethylene. The triplet $\left[\mathrm{H}-\mathrm{Si}_{2}-\mathrm{H}\right]^{2-}$ lies ca. $20 \mathrm{kcal} / \mathrm{mol}$ above the singlet $\left[\mathrm{H}-\mathrm{Si}_{2}-\mathrm{H}\right]^{2-}$. The highest occupied molecular orbital (HOMO) and the lowest unoccupied molecular orbital (LUMO) of the singlet $\left[\mathrm{H}-\mathrm{Si}_{2}-\mathrm{H}\right]^{2-}$ in cis and trans configurations are $\pi$ and $\pi^{*}$, respectively. Lone pair orbital exists at each silicon atom instead of $\mathrm{C}-\mathrm{H}$ bonding orbital in ethylene. It is concluded that dianionic $\mathrm{H}-\mathrm{Si}_{2}-\mathrm{H}$ shows the feature of double-bond compound like ethylene in the existence of the cis and trans isomers and in the character of HOMO and LUMO. The formation of doubly bonded species by doping two electrons is qualitatively explained from the donor-accepter bonding scheme of the trans bending disilyne and monobridged $\mathrm{Si}_{2} \mathrm{H}_{2}$ (Fig. 2): when two electrons are doped in two vacant $\mathrm{p}$ orbitals, one by one, two donor-acceptor bonds are broken and then a new $\sigma$ bond and two lone pair orbitals are constructed.
Very recently, after our theoretical design, a doubly bonded silicon dimer in trans configuration with lone pair orbitals at silicon was experimentally synthesized (Wang et al. 2008): a carbene-stabilized L:Si=Si:L ( $\mathrm{L}:=: \mathrm{C}\{\mathrm{N}(2,6-$ $\left.\left.\operatorname{Pr}_{2}^{i} \mathrm{C}_{6} \mathrm{H}_{3}\right) \mathrm{CH}\right\}_{2}$ ) with $\mathrm{Si}$ atoms in the formal oxidation of zero. The $\mathrm{Si}-\mathrm{Si}$ bond distance in the carbene-stabilized diatomic silicon molecule is $2.229 \AA$, which is consistent with a double bond. The lone-pair molecular orbitals of the heterocyclic carbene ligand coordinate to vacant $\mathrm{p}$ orbital of central silicon atoms and the excess electrons form lone-pair orbitals at silicon.

\section{Metal-substituted disilyne with a linear Si-Si triple-bond skeleton}

In this section, we describe our systematic search for stable linear disilynes $\mathrm{ESi}=\mathrm{SiE}$ by $a b$ initio and densityfunctional-theory calculations (Takahashi and Kawazoe 2008). Numerous investigations on the substituent effects of disilynes aiming at the linear form have been performed so far, but this is the first attempt at the use of metal atom as a substituent.

A triple bond is classically seen to have a linear structure with a very short bond distance, as found in acetylene $(\mathrm{HC} \equiv \mathrm{CH})$. A symmetry-separated set of one $\sigma$ and two degenerate $\pi$ molecular orbitals describes the set of six valence electrons in a triple bond in a common molecular orbital theory using delocalized orbitals. Submillimeter-wave rotational spectroscopic studies of a low-power silane plasma have revealed the structures of a doubly hydrogenbridged $\mathrm{H}_{2} \mathrm{Si}_{2}$ with a Si-Si bond length of $2.208 \AA$ and
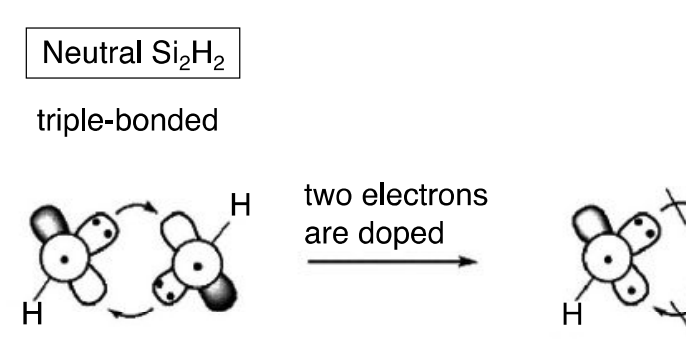

Dianionic $\mathrm{Si}_{2} \mathrm{H}_{2}{ }^{2-}$

trans configuration
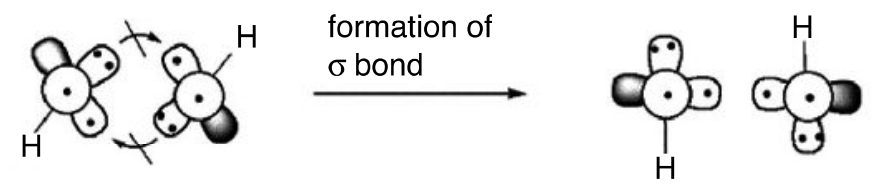

monobridged

cis configuration
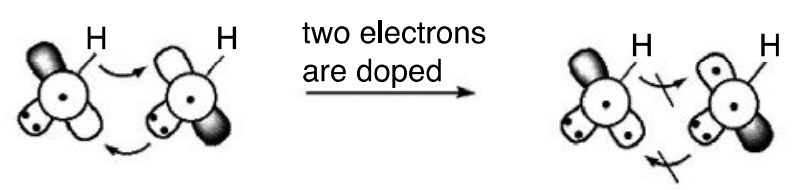

formation of

$\sigma$ bond

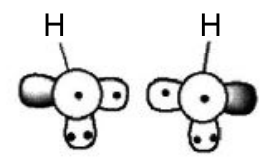

Fig. 2. The formation of doubly bonded species with two electrons doped. 
singly hydrogen-bridged $\mathrm{H}_{2} \mathrm{Si}_{2}$ with a very short $\mathrm{Si}-\mathrm{Si}$ separation of $2.119 \AA$ (Bogey et al. 1991; Cordonnier et al. 1992). The experiment verified an earlier theoretical prediction of the doubly hydrogen-bridged structure as the global minimum of the $\mathrm{H}_{2} \mathrm{Si}_{2}$ singlet potential surface (Lischka and Köhler 1983). The monobridged structure is the second most stable isomer of $\mathrm{H}_{2} \mathrm{Si}_{2}$ (Colegrove and Schaefer 1990; Grev and Schaefer 1992). An acetylene analogue with $D_{\infty o h}$ symmetry does not even correspond to a minimum on the potential surface and distorts to a $C_{2 h^{-}}$ symmetric trans-bent form (reviewed in (Grev 1991)). The bending is accompanied by a loss of $\pi$-bond strength and lowering of the bond order (Bridgeman and Ireland 2001; Grunenberg 2001). The X-ray crystallographic structure of an isolated stable disilyne (1,1,4,4-tetrakis[ bis(trimethylsilyl)methyl]-1,4-diisopropyl-2-tetrasilyne) with a formal $\mathrm{Si}-\mathrm{Si}$ triple bond is trans bending with a bond angle of $137.44^{\circ}$, and the four Si atoms are perfectly coplanar (Sekiguchi et al. 2004). The Si-Si triple-bond distance $(2.14 \AA)$ is $13.5 \%$ shorter than the average single bond $(2.34 \AA)$. Though the natural bond order analysis of the disilyne gives a value of 2.618 , indicating a nearly genuine triple bond, the value is still less than that of 3 for acetylene. It has been shown theoretically that substitution by electropositive silyl groups is electronically much more effective in realizing a less trans-bent disilyne structure (Kobayashi and Nagase 1997; Nagase et al. 2000). However, neither theoretical nor experimental attempt succeeded in obtaining a linear $D_{\infty h^{\prime}}$-symmetric geometry as the global minimum.

Since disilyne with an electropositive silyl group has a less trans-bent structure, we utilize metal elements as a much more electropositive substituent (Fig. 3). Geometries of singlet $\mathrm{ESi}=\mathrm{SiE}$ were optimized under the constraint of $D_{o c h}$ symmetry. Their NPA charge at silicon is negative, indicating that the metals act as an electron donor. A classical triple-bond structure, that is a linear form with a Wiberg bond index of approximate 3 , is obtained as a minimum only for divalent-metal-substituted disilynes $(\mathrm{ESi}=\mathrm{SiE} ; \mathrm{E}=\mathrm{Be}, \mathrm{Mg}, \mathrm{Ca}, \mathrm{Zn})$, where the atomic electron configuration of the metals is $s^{2}$. The monovalent-metalsubstituted disilynes $(\mathrm{ESi} \equiv \mathrm{SiE} ; \mathrm{E}=\mathrm{Li}, \mathrm{Na}, \mathrm{K}, \mathrm{Cu})$, where the atomic electron configuration of the metals is $s^{l}$, are second-order saddle points, though the disilynes have a Wiberg bond index of approximate 3 in the linear form. Six valence electrons are accommodated in one $\sigma$ and two degenerate $\pi$ molecular orbitals in both divalent- and monovalent-metal-substituted disilynes. The realization of the classical triple bond only in divalent-metal-substituted disilynes is explained by the suppression of $\sigma-\pi$ mixing. A donor-acceptor bonding model has well explained the trans-bent structure of disilyne $(\mathrm{HSi}=\mathrm{SiH})$, where a triple bond weakened by distortion from a classical linear structure is stabilized by the delocalization of the $n_{\sigma}$ lone electron pair of one $\mathrm{SiH}$ into the empty $\mathrm{p}_{\pi}{ }^{*}$ atomic orbital of its partner in the valence bond scheme. Explaining the donor-acceptor bonding model in the molecular orbital scheme, the distorted structure is stabilized by $\sigma-\pi$ mixing. The $\sigma-\pi$ mixing would be suppressed in the divalentmetal-substituted disilynes by HOMO, which is neither $\sigma$ nor $\pi$ orbital. The remarkable difference of the linear monovalent substituent from the linear divalent substituent is the HOMO of $\pi$ orbital.

$$
\begin{gathered}
\text { metal } \mathrm{Si} \equiv \mathrm{Si} \underset{\text { metal }}{\mathrm{O}} \\
\left\{\begin{array}{l}
s^{1}: \mathrm{Li}, \mathrm{Na}, \mathrm{K}, \mathrm{Cu} \\
s^{2}: \mathrm{Be}, \mathrm{Mg}, \mathrm{Ca}, \mathrm{Zn} \\
d^{n}: \mathrm{Sc}, \mathrm{Ti}, \mathrm{V}, \mathrm{Cr}, \mathrm{Mn}, \mathrm{Fe}, \mathrm{Co}, \mathrm{Ni}
\end{array}\right.
\end{gathered}
$$

Fig. 3. Metal-substituted disilynes with $D_{\propto \infty h}$ symmetry.

To render the linear disilyne synthetically more accessible, we designed the Mg-substituted disilyne using the magnesium complex of core-modified porphyrin. The magnesium oxidation number in the magnesium complex of coremodified porphyrin is desired here to be 0 for magnesium to act as an electron donor to silicon, and thus we use the magnesium complex of 21,23-dioxaporphyrin, which was recently synthesized (Punidha et al. 2004). The optimized Si-Si bond distance (2.108 $\AA$ ) of the disilyne with the magnesium complex of 21,23-dioxaporphyrin is slightly longer than that of $\mathrm{MgSi} \equiv \mathrm{SiMg}(2.092 \AA)$, but is shorter than the usual Si-Si double bond (2.14 $\AA$ ). It is noted here that the charge transfer between the $\mathrm{Si}$ and $\mathrm{Mg}$ atoms is reproduced (NPA charges are -0.392 at $\mathrm{Si}$ and 1.243 at $\mathrm{Mg}$ ).

\section{Anionic polysilicon chains with a planar $\pi$-conjugating skeleton}

We extend our topics to hydrogen-terminated $\mathrm{H}-\mathrm{Si}_{n}-\mathrm{H}$ ( $\mathrm{n}$ $=4,6,8)$ oligomers (Takahashi and Kawazoe 2005). As the number of silicon atoms increases, the number of isomers of the silicon hydrides $\mathrm{Si}_{n} \mathrm{H}_{2}$ increases tremendously. We 
are interested in one-dimensional conjugation and thus consider here planar trans-zigzag chains. The optimization was performed under the constraint of planarity. Six equilibrium chains are obtained with even number of electrons and no neutral chain is obtained as a minimal structure. Optimized $\mathrm{Si}_{4} \mathrm{H}_{2}{ }^{4-}$ possesses an approximate $120^{\circ}$ of $\mathrm{Si}-\mathrm{Si}-\mathrm{Si}$ bond angle and two short and one long $\mathrm{Si}-\mathrm{Si}$ bonds, suggesting two double and one single bonds, and $s p^{2}$ hybridization at silicon. The $\mathrm{Si}-\mathrm{Si}$ bond distances are long compared to the corresponding single and double bonds of neutral silicon compounds probably due to strong electron repulsion in the present multiply anionic system. From a natural bond orbital (NBO) analysis, it is proved that 20 doubly occupied core, seven bonding, and four lone pair orbitals exist in $\left[\mathrm{H}-{ }^{1} \mathrm{Si}_{-}{ }^{2} \mathrm{Si}-{ }^{3} \mathrm{Si}-{ }^{4} \mathrm{Si}-\mathrm{H}\right]^{4}$. The seven bonding orbitals are two ${ }^{1} \mathrm{Si}-{ }^{2} \mathrm{Si}$, two ${ }^{3} \mathrm{Si}-{ }^{4} \mathrm{Si}$, one ${ }^{2} \mathrm{Si}-3 \mathrm{Si}$, and two $\mathrm{Si}-\mathrm{H}$ bonds. The hybridization at ${ }^{1} \mathrm{Si}$ and ${ }^{4} \mathrm{Si}$ are $p_{\pi}$ and $s p^{2.05}$. Each silicon atom has a lone-pair orbital. The lone-pair orbital in $\left[\mathrm{H}^{-}{ }^{1} \mathrm{Si}^{-}{ }^{2} \mathrm{Si}-{ }^{3} \mathrm{Si}-{ }^{4} \mathrm{Si}-\mathrm{H}\right]^{4}$ looks like a $\mathrm{C}-\mathrm{H}$ bonding orbital at each carbon atom in butadiene $\left(\mathrm{H}_{2} \mathrm{C}=\mathrm{CHCH}=\mathrm{CH}_{2}\right)$. From the structure and the hybridization, the planar $\mathrm{Si}_{4} \mathrm{H}_{2}{ }^{4-}$ oligomer is a chain that strictly mimics butadiene (type I in Fig. 4). The $\mathrm{Si}-$ $\mathrm{Si}-\mathrm{Si}$ bond angles of optimized dianion $\mathrm{Si}_{4} \mathrm{H}_{2}{ }^{2-}$ are large $\left(140^{\circ}\right)$ and $\mathrm{Si}-\mathrm{Si}$ bond lengths are short compared with those of $\mathrm{Si}_{4} \mathrm{H}_{2}{ }^{4}$. The $\mathrm{Si}-\mathrm{Si}-\mathrm{Si}$ bond angle of $140^{\circ}$ is close to the experimentally observed $\mathrm{Si}-\mathrm{Si}-\mathrm{Si}$ bond angle of trisilaallene (Ishida et al. 2003). From an NBO analysis, eight bonding orbitals and two lone pair orbitals are found. The eight bonding orbitals are three $\mathrm{Si}-\mathrm{Si}$ double bonds and two Si-H bonds. Two of three $\pi$ orbitals are out-of-plane at ${ }^{1} \mathrm{Si}-{ }^{2} \mathrm{Si}$ and ${ }^{3} \mathrm{Si}-{ }^{4} \mathrm{Si}$ and one is in-plane at ${ }^{2} \mathrm{Si}-{ }^{3} \mathrm{Si}$. Two lone pair orbitals are located at ${ }^{1} \mathrm{Si}$ and ${ }^{4} \mathrm{Si}$ like a $\mathrm{C}-\mathrm{H}$ bonding orbital at each carbon atom in allene $\left(\mathrm{H}_{2} \mathrm{C}=\mathrm{C}=\mathrm{CH}_{2}\right)$. The Lewis structure of $\mathrm{Si}_{4} \mathrm{H}_{2}{ }^{2-}$ is a chain of three double bonds with lone pair electrons at two terminal silicon atoms (type II in Fig. 4).
Next, we consider a neutral acyclic $\mathrm{Si}^{4}$ oligomer where the substituents at the terminals act as an electron donor. This molecule is neutral, but the silicon chain is electronrich because the terminal substituents push electrons into the silicon chain. Since the amino group is known as a $\pi$-electron donating substituent, we consider the diamino substituent of silicon tetramer, $\mathrm{H}_{2} \mathrm{~N}-{ }^{1} \mathrm{Si}-{ }^{2} \mathrm{Si}-{ }^{3} \mathrm{Si}-{ }^{4} \mathrm{Si}-\mathrm{NH}_{2}$. One short and two long $\mathrm{Si}-\mathrm{Si}$ bonds and the $\mathrm{Si}-\mathrm{Si}-\mathrm{Si}$ bond angles of approximate $120^{\circ}$ are obtained. From an NBO analysis, three out-of-plane $\pi$ orbitals are located at $\mathrm{N}-{ }^{1} \mathrm{Si},{ }^{2} \mathrm{Si}-{ }^{3} \mathrm{Si}$, and ${ }^{4} \mathrm{~S}-\mathrm{N}$, and the sum of occupation of the out-of-plane $\pi$ orbitals is 5.89 . Lone pair orbitals are located at ${ }^{1} \mathrm{Si}$ and ${ }^{4} \mathrm{Si}$, and one in-plane $\pi$ orbital at ${ }^{2} \mathrm{Si}-{ }^{3} \mathrm{Si}$. The molecule is regarded as the third type of $\mathrm{Si}_{4}$ oligomer (type III of Fig. 4).

Six-atom and eight-atom silicon oligomers with four and six excess electrons were optimized and four planar equilibrium structures were obtained $\left(\mathrm{Si}_{6} \mathrm{H}_{2}{ }^{4-}, \mathrm{Si}_{6} \mathrm{H}_{2}{ }^{6-}\right.$, $\left.\mathrm{Si}_{8} \mathrm{H}_{2}{ }^{4-}, \mathrm{Si}_{8} \mathrm{H}_{2}{ }^{6-}\right)$. The optimized structures are constructed from a part of the three types of $\mathrm{Si}_{4}$ oligomers. An NBO analysis reveals that the number of $\pi$ electrons formally accommodated in the out-of-plane $\pi$ orbitals is the same as the number of silicon atoms and is independent of the number of electrons doped into the planar polysilicon chains: the out-of-plane $\pi$ orbital occupations sum up to 3.88 for $\mathrm{Si}_{4} \mathrm{H}_{2}{ }^{2-}, 3.88$ for $\mathrm{Si}_{4} \mathrm{H}_{2}{ }^{4}, 5.67$ for $\mathrm{Si}_{6} \mathrm{H}_{2}{ }^{4}, 5.60$ for $\mathrm{Si}_{6} \mathrm{H}_{2}^{6-}, 7.39$ for $\mathrm{Si}_{8} \mathrm{H}_{2}^{4}$, and 7.42 for $\mathrm{Si}_{8} \mathrm{H}_{2}^{6-}$. The difference of the number of doped electrons appears in the number of lone-pair electrons.

\section{Benzene-like and doubly aromatic six-membered rings of silicon}

In this section, we focus on a planar six-membered ring. Planar six-membered rings are closely related to a two-dimensional aromaticity, and anionic six-membered germanium and silicon rings with $D_{6 h}$ symmetry are
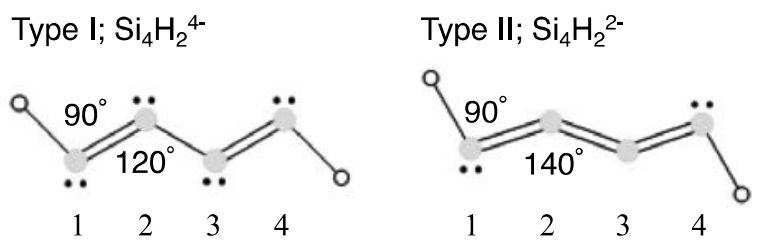

Type III; $\mathrm{Si}_{4}\left(\mathrm{NH}_{2}\right)_{2}$

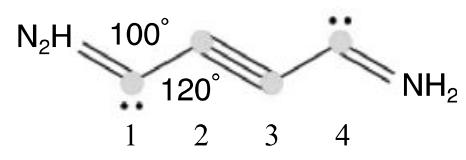

Fig. 4. Three types of $\mathrm{Si}_{4}$ chains. 
recently reviewed (Takahashi 2010). By doping two and six electrons, we obtain planar $\mathrm{c}-\mathrm{Si}_{6}$ molecules with $D_{6 h}$ symmetry as a minimum. Four-electron doped c- $\mathrm{Si}_{6}$ molecule is an equilibrium structure, but the symmetry is $D_{2 h}$ not $D_{6 h}$. We could not locate a minimum at a neutral $D_{6 h}$-symmetric c-Si ${ }_{6}$. An NBO analysis of $D_{6 h}{\mathrm{c}-\mathrm{Si}_{6}{ }^{6-}}^{-}$ shows 30 doubly occupied core orbitals as well as nine bonding and six lone pair orbitals. Among nine $\mathrm{Si}-\mathrm{Si}$ bonding orbitals, six bonds have $s p^{2.1}$ hybridization and three bonds $p_{\pi}$ hybridization. Six lone pair orbitals exist at silicon instead of six C-H bonding orbitals in benzene.


a six- $\pi$-electrons ring with a $s p^{2}$ silicon backbone like benzene, but the $\mathrm{Si}-\mathrm{Si}$ bond distances are longer (2.378 $\AA$ ) than that of the $\mathrm{Si}-\mathrm{Si}$ single bond of a neutral silicon compound.

The bonding nature of $D_{6 h}$-symmetric $\mathrm{Si}_{6}^{2-}$ is remarkably different from benzene and from $D_{6 h}$-symmetric $\mathrm{Si}_{6}{ }^{6-}$ as well. The NBO analysis showed six p-type orbitals and six $\sigma$ orbitals with $s p^{1.6}$ and $s p^{0.8}$ hybridizations as a bonding orbital. The six p-type orbitals are three $\mathrm{Si}-\mathrm{Si}$ bonds with $s p^{14.8}$ hybridization and three $\mathrm{Si}-\mathrm{Si}$ bonds with $p_{\pi}$ hybridization. Three of the six p-type orbitals are in the molecular plane and the other three are out of the molecular plane. The three in-plane radial-type $p$ orbitals overlap in the center, resulting in $\sigma$-bonding and contributing to $\sigma$-aromaticity. $\mathrm{The}_{\mathrm{Si}}{ }^{2-}$ contains two 6-electron conjugated systems in perpendicular planes. Two orthogonal Hückel frameworks within a single molecule are first conceived in 1979 (Chandrasekher et al. 1979) and are named "double aromaticity". Later, the appearance of double aromaticity in $D_{6 h}$ cyclic $\mathrm{C}_{6}$ cluster was reported (Schleyer et al. 1994). The Wiberg bond indexes of the neighboring $\mathrm{Si}-\mathrm{Si}$ bonds on the perimeter of hexagon and diametrical Si-Si bonds are 1.587 and 0.361 . The values are larger than those of benzene (1.441 and 0.114). The doubly aromatic $D_{6 h}$ cyclic $\mathrm{C}_{6}$ cluster shows larger Wiberg bond indexes for the two types of $\mathrm{C}-\mathrm{C}$ bonds as well, compared with aromatic benzene. The difference of $\mathrm{Si}_{6}{ }^{2-}$ from the doubly aromatic $D_{6 h}$ cyclic $\mathrm{C}_{6}$ cluster is that the $\mathrm{Si}_{6}{ }^{2-}$ cluster is dianion. The $\sigma$ and $\sigma^{*}$ orbitals accommodate a total of 14 electrons, where the extra two electrons in $\sigma^{*}$ orbitals leads to dianion. The $\mathrm{Si}-\mathrm{Si}$ bond length of $2.24 \AA$ is between the $\mathrm{Si}-\mathrm{Si}$ single and double bonds. It is interesting that the total number of $\pi$ electrons accommodated in the out-of-plane $\pi$ orbitals is six in both $D_{6 h}$-symmetric $\mathrm{Si}_{6}{ }_{6}{ }^{6-}$ and $\mathrm{Si}_{6}{ }^{2-}$, that is independent of the number of doped electrons.

From the symmetry and the number of out-of-plane $\pi$ electrons revealed by the NBO analysis, the $\mathrm{Si}_{6}{ }^{2-}$ and $\mathrm{Si}_{6}{ }_{6}{ }^{6-}$ hexagons are candidates for aromatic six-membered silicon rings. Nucleus independent chemical shift (NICS) is a well-known index of aromaticity (Schleyer et al. 1996; Schleyer et al. 1997; West et al. 1998). NICS evaluates the aromaticity/antiaromaticity using absolute magnetic shieldings computed at ring centers with an available quantum mechanics program. To correlate to a familiar convention of NMR chemical shift, the signs of the computed magnetic shielding values are reversed. The proposal of NICS as an aromaticity probe is based on the observation of abnormal chemical shifts of protons located inside the aromatic ring current. Positive NICS values denote antiaromaticity and negative ones aromaticity. To weaken the local contributions of nearby $\sigma$ bonds, the measuring point of the NMR chemical shift is placed 2 $\AA$ away above the ring center in the later refinement. The best performing NICS aromaticity index is $\operatorname{NICS}(0)_{\pi z z}$, $\pi$ molecular orbital contribution to the zz component of the NICS tensor of the molecule in the XY plane (FallahBagher-Shaidaei et al. 2006). On the other hand, a more readily available, easy to use, and very good alternative NICS index is NICS $(1)_{z}$, total molecular orbital contribution to the zz component of the NICS tensor computed $1 \AA$ away from the center above rings. The NICS values of $D_{\sigma h^{-}}$ symmetric $\mathrm{Si}_{6}{ }_{6}^{6-}$ and $D_{6 h}$-symmetric $\mathrm{Si}_{6}{ }^{2-}$ were calculated to be positive indicating antiaromaticity and negative indicating aromaticity, respectively. Unfortunately, $D_{\sigma h^{-}}$ symmetric $\mathrm{Si}_{6}{ }^{6-}$ is antiaromatic, though the Lewis structure is similar to aromatic benzene. It would be due to the long $\mathrm{Si}-\mathrm{Si}$ bond length of $D_{6 h}$-symmetric $\mathrm{Si}_{6}{ }^{6-}$ and thus the weak $\pi$ interaction. The NICS value of $D_{6 h}$-symmetric $\mathrm{Si}_{6}{ }^{2-}$ has a minimum around $1.5 \AA$ above the ring, which means $\pi$-ring current causes the chemical shift (West et al. 1998). It turns out that the $D_{6 h}$-symmetric $\mathrm{Si}_{6}{ }^{2-}$ is doubly aromatic from NBO analysis and it was confirmed from the NICS values that the out-of-plane $\pi$ electrons in the doubly aromatic $\mathrm{Si}_{6}^{2-}$ actually shows aromaticity. Since the most stable, and thus the most preferable isomer of $\mathrm{Si}_{6}^{2-}$ is octahedron (Takahashi and Kawazoe 2006) same as anionic six-atoms germanium clusters (Kikuchi et al. 2006), in accord with Wade's rule, a kinetic stabilization preventing isomerization to octahedron is required to obtain the less stable planar and hexagonal $\mathrm{Si}_{6}{ }^{2-}$. 


\section{Conclusions}

In this paper, we have summarized our findings presented in (Takahashi and Kawazoe 2005; Takahashi and Kawazoe 2006; Takahashi and Kawazoe 2008, Takahashi 2010). Our goal has been to design the strictly genuine $\pi$-electron silicon system. After the introduction of an essential history in the unsaturated silicon chemistry from the theoretical and synthetic points of view, we stated fundamental building blocks of $\pi$-electron silicon nanomaterials computed for anionic system by us in the latter sections: a hydrogenterminated silicon dimer with a planar double bond character, a silicon-silicon triple bond with a linear form, planar trans-zigzag chains, and six-membered silicon rings. What we would emphasize is that our pioneer work stimulated the synthetic attempt (Wang et al. 2008) and further theoretical investigations (Zdetsis 2007; Santos and Fuentealba 2007).

We discuss finally the reason why the classical form was found in anionic system against the multiple-bond rule. It is well known that the silicon-silicon triple-bond compound is trans-bending and the six-membered silicon ring puckered in a chair-like form, both due to $\sigma-\pi$ mixing as indicated by a donor-acceptor model. However, the anionic building blocks found by us prefer classical structures such as linear in triple bond and planar in sixmembered ring. A common electronic feature among our building blocks providing classical structures such as linear triple bond and $D_{6 h}$-symmetric hexagon is the existence of occupied molecular orbitals above occupied out-of-plane $\pi$ orbitals; those would prevent the $\sigma-\pi$ mixing.

\section{Acknowledgements}

This review highlights the author's winning work of the SJWS (the Society of Japanese Women Scientists) promising science award in 2010 entitled "The construction of building blocks for highly functional $\pi$-electron silicon nanomaterials by first-principles calculations". The award has been granted annually to honor a few woman scientists for their outstanding achievements in science. The author's works presented in this review were performed at institute for materials research, Tohoku University and the author is grateful to all colleagues in the cited references.

\section{References}

Bogey M, Bolvin H, Demuynck C and Destombes JL (1991) Nonclassical double-bridged structure in siliconcontaining molecules: Experimental evidence in $\mathrm{Si}_{2} \mathrm{H}_{2}$ from its submillimeter-wave spectrum. Phys. Rev. Lett. 66 (4): 413-416.

Bridgeman AJ and Ireland LR (2001) Multiple bonding in Groups 13 and 14 homonuclear ethyne analogues. Polyhedron 20: 2841-2851.

Chandrasekher J, Jemmis ED and Schleyer PvR (1979) Double aromaticity: Aromaticity in orthogonal planes. The 3,5-dehydrophenyl cation. Tetrahedron Lett. (39): 3707-3710.

Colegrove BT and Schaefer HF III (1990) Disilyne $\left(\mathrm{Si}_{2} \mathrm{H}_{2}\right)$ revisited. J. Phys. Chem. 94 (14): 5593-5602.

Cordonnier M, Bogey M, Demuynck C and Destombes J-L (1992) Nonclassical structures in silicon-containing molecules: The monobridged isomer of $\mathrm{Si}_{2} \mathrm{H}_{2}$. J. Chem. Phys. 97 (11): 7984-7989.

Fallah-Bagher-Shaidaei H, Wannere CS, Corminboeuf C, Puchta R and Schleyer PvR (2006) Which NICS aromaticity index for planar $\pi$ rings is best? Org. Lett. 8 (5): 863-866.

Fink MJ, Michalczyk MJ, Haller KJ, West R and Michl J (1983) The X-ray crystal structure of tetramesityldisilene. J. Chem. Soc., Chem. Commun.: 1010-1011.

Grev RS and Schaefer HF III (1992) The remarkable monobridged structure of $\mathrm{Si}_{2} \mathrm{H}_{2}$. J. Chem. Phys. 97 (11): 7990-7998.

Grev RS (1991) Structure and bonding in the parent hydrides and multiply bonded silicon and germanium compounds: From $\mathrm{MH}_{\mathrm{n}}$ to $\mathrm{R}_{2} \mathrm{M}=\mathrm{M}^{\prime} \mathrm{R}_{2}$ and $\mathrm{RM} \equiv \mathrm{M}^{\prime} \mathrm{R}$. Adv. Organomet. Chem. 33: 125-170.

Grunenberg J (2001) Intrinsic bond strengths of multiple $\mathrm{C}-\mathrm{C}, \mathrm{Si}-\mathrm{Si}$, and $\mathrm{C}-\mathrm{Si}$ bonds. Angew. Chem. Int. Ed. 40 (21): 4027-4029.

Hotop H and Lineberger WC (1985) Binding energies in atomic negative ions: II. J. Phys. Chem. Ref. Data 14 (3): 731-750.

Ishida S, Iwamoto T, Kabuto C and Kira M (2003) A stable silicon-based allene analogue with a formally $s p$-hybridized silicon atom. Nature 421: 725-727.

Jutzi P (1975) New element-carbon (p-p) $\pi$ bonds. Angew. Chem. Int. Ed. Engl. 14 (4): 232-245.

Jutzi P (2000) Stable systems with a triple bond to silicon or its homologues: Another challenge. Angew. Chem. 
Int. Ed. 39 (21): 3797-3800.

Karni M and Apeloig Y (1990) Substituent effects on the geometries and energies of the $\mathrm{Si}=\mathrm{Si}$ double bond. J. Am. Chem. Soc. 112: 8589-8590.

Kikuchi H, Takahashi M and Kawazoe Y (2006) Theoretical investigation of stable structures of $\mathrm{Ge}_{6}$ clusters with various negative charges. Mater. Trans. 47 (11): 26242628.

Kobayashi K and Nagase S (1997) Silicon-silicon triple bonds: Do substituents make disilynes synthetically accessible? Organometallics 16 (12): 2489-2491.

Koseki S and Gordon MS (1988) Theoretical study of the lowest triplet potential energy surface of $\mathrm{Si}_{2} \mathrm{H}_{2}$. J. Phys. Chem. 92 (2): 364-367.

Kutzelnigg W (1984) Chemical bonding in higher main group elements. Angew. Chem. Int. Ed. Engl. 23: 272295.

Lischka H and Köhler H-J (1983) Ab initio investigation on the lowest singlet and triplet state of $\mathrm{Si}_{2} \mathrm{H}_{2}$. J. Am. Chem. Soc. 105 (22): 6646-6649.

Nagase S, Teramae H and Kudo T (1987) Hexasilabenzene $\left(\mathrm{Si}_{6} \mathrm{H}_{6}\right)$. Is the benzene-like $D_{6 h}$ structure stable? J. Chem. Phys. 86 (8): 4513-4517.

Nagase S (1991) Interesting properties of the heavier Group 14 analogues of aromatic and polycyclic carbon compounds. A theoretical study. Polyhedron 10 (11): 1299-1309.

Nagase S, Kobayashi K and Takagi N (2000). Triple bonds between heavier Group 14 elements. A theoretical approach. J. Organomet. Chem. 611: 264-271.

Nesper R, Currao A and Wengert S (1998) Nonaromatic planar $\mathrm{Si}_{12}$ ring system of approximate $D_{6 h}$ symmetry in $\mathrm{Ca}_{7} \mathrm{Mg}_{7.5 \pm \delta} \mathrm{Si}_{14}$. Chem. Eur.J. 4 (11): 2251-2257.

Punidha S, Agarwal N, Burai R and Ravikanth M (2004) Synthesis of $\mathrm{N}_{3} \mathrm{~S}, \mathrm{~N}_{3} \mathrm{O}, \mathrm{N}_{2} \mathrm{~S}_{2}, \mathrm{~N}_{2} \mathrm{O}_{2}, \mathrm{~N}_{2} \mathrm{SO}$ and $\mathrm{N}_{2} \mathrm{OS}$ porphyrins with one meso-unsubstituted carbon. Eur. J. Org. Chem.: 2223-2230.

Raabe G and Michl J (1985) Multiple Bonding to Silicon. Chem. Rev. 85 (5): 419-509.

Santos JC and Fuentealba P (2007) Aromaticity and electronic structure of silabenzenes. Possible existence of a new cluster $\mathrm{Si}_{6} \mathrm{Li}_{6}$. Chem. Phys. Lett. 443: 439-442.

Schleyer PvR, Jiao H, Glukhovtsev MN, Chandrasekhar J and Kraka E (1994) Double aromaticity in the 3,5dehydrophenyl cation and in cyclo[6]carbon. J. Am. Chem. Soc. 116 (22): 10129-10134.

Schleyer PvR, Maerker C, Dransfeld A, Jiao H and Hommes
NJRvE (1996) Nucleus-independent chemical shifts: A simple and efficient aromaticity probe. J. Am. Chem. Soc. 118 (26): 6317-6318.

Schleyer PvR, Jiao H, Hommes NJRvE, Malkin VG and Malkina OL (1997) An evaluation of the aromaticity of inorganic rings: Refined evidence from magnetic properties. J. Am. Chem. Soc. 119 (51): 12669-12670.

Schnering HG, Bolle U, Curda J, Peters K, Carrillo-Cabrera W, Somer M, Schultheiss M and Wedig U (1996) Hückel arenes with ten $\pi$ electrons: Cyclic Zintl anions $\mathrm{Si}_{6}{ }^{10-}$ and $\mathrm{Ge}_{6}{ }^{10-}$, isosteric to $\mathrm{P}_{6}{ }^{4-}$ and $\mathrm{As}_{6}{ }^{4-}$. Angew. Chem. Int. Ed. Engl. 35 (9): 984-986.

Sekiguchi A, Kinjo R and Ichinohe M (2004) A stable compound containing a silicon-silicon triple bond. Science 305: 1755-1757.

Takahashi M and Sakamoto K (2002) Structures and stabilities of heteroatom-substituted disilenes and related compounds: Four-center $\pi$ systems. Organometallics 21 (20): 4212-4216.

Takahashi M and Kawazoe Y (2005) Theoretical study on planar anionic polysilicon chains and cyclic $\mathrm{Si}_{6}$ anions with $D_{6 h}$ symmetry. Organometallics 24 (10): 2433 2440 .

Takahashi M and Kawazoe Y (2006) Theoretical proposal of planar silicon oligomer and silicon benzene, Comput. Mater. Sci. 36: 30-35.

Takahashi M and Kawazoe Y (2006) Ab initio quantum chemical investigation of several isomers of anionic $\mathrm{Si}_{6}$. Chem. Phys. Lett. 418: 475-480.

Takahashi M and Kawazoe Y (2008) Metal-substituted disilynes with linear forms. Organometallics 27 (19): 4829-4832.

Takahashi M (2010) Polyanionic hexagons: $\mathrm{X}_{6}{ }^{\mathrm{n}-}(\mathrm{X}=\mathrm{Si}$, Ge). Symmetry 2: 1745-1762.

Wang Y, Xie Y, Wei P, King RB, Schaefer HF III, Schleyer PvR and Robinson GH (2008) A stable silicon(0) compound with a $\mathrm{Si}=\mathrm{Si}$ double bond. Science 321 : 1069-1071.

West R, Fink MJ and Michl J (1981) Tetramesityldisilene, a stable compound containing a silicon-silicon double bond. Science 214: 1343-1344.

West R, Buffy JJ, Haaf M, Müller T, Gehrhus B, Lappert MF and Apeloig Y (1998) Chemical shift tensors and NICS calculations for stable silylenes. J. Am. Chem. Soc. 120 (7): 1639-1640.

Zdetsis AD (2007) Stabilization of flat aromatic $\mathrm{Si}_{6}$ rings analogues to benzene: $\mathrm{Ab}$ initio theoretical prediction. 


\title{
第一原理計算による高機能性ケイ素 $\pi$ 電子ナノ材料の基本単位の構築
}

\author{
高橋まさえ
}

東北大学大学院農学研究科

要旨: 本総説では、高機能性ケイ素 $\pi$ 電子ナノ材料の厳密に本来の $\pi$ 電子をもつ基本単位の構 築に関する我々の第一原理計算による研究を紹介寸る。ケイ素は炭素と同族であるが、不飽和ケ イ素化合物の構造は不飽和炭素化合物と異なりいわゆる非古典的であることが知られている。即 ち、ケイ素二重結合および三重結合化合物はトランス折れ曲がり構造をしており、ケイ素六員環 は椅子型構造をしている。我々は、最近、従来のアルキル基、アリール基などの置換基のかわり に電子を使うことで、直線型 $D_{\infty h}$ 対称性ケイ素三重化合物や $D_{6 h}$ 対称性ケイ素六員環など厳密に本 来の $\pi$ 電子をもつ基本単位を理論的に設計することに成功した。主に我々の発見をまとめるとと もに、ケイ素 $\pi$ 電子系の古典的構造を実現するための鍵となる点について議論する。

キーワード:第一原理計算、密度汎関数理論計算、ケイ素 $\pi$ 電子系、アニオン性ケイ素クラスター、 芳香族性、二重芳香族性 